\title{
Social Aspect as a Component in the Practice of the Caucasus Region Ruled by Governor-General in the 40s-50s of XIX Century
}

\author{
Sergey Stepanovich Lazaryan ${ }^{1} \&$ Akhurbek Alikhanovich Magometov ${ }^{2}$ \\ ${ }^{1}$ Pyatigorsk State Linguistic University, Russian Federation \\ ${ }^{2}$ North Ossetian State University, Vladikavkaz, Russian Federation \\ Correspondence: Sergey Stepanovich Lazaryan, Kalinina street, 9, Pyatigorsk, 357500, Russian Federation. \\ E-mail: biz.fgsu@pglu.ru
}

\author{
Received: February 27, 2015 Accepted: April 25, 2015 Online Published: July 30, 2015 \\ doi:10.5539/ass.v11n19p56 URL: http://dx.doi.org/10.5539/ass.v11n19p56
}

\begin{abstract}
The article is dedicated to the social aspects of the Russian administration in the Caucasus region under the rule of Governor-general M. S. Vorontsov, who used philanthropy and other means of public participation in the cause of finding ways towards the economic and socio-cultural prosperity of the region.
\end{abstract}

Keywords: the Caucasus region, governor-general, philanthropy, public forces, donation, the needy people, aid to the needy people, the Caucasus corps commander, certificated doctors

\section{Introduction}

Before covering the social aspects in the everyday practice of the governor-general of the Caucasus prince M.S. Vorontsov it should be emphasized that this problem has never before been the central object of the research, at least from the declared angle.

Up to now both predecessors and the contemporary researchers of the Caucasus, if they have touched upon the social aspects of the work of the authorized representatives of the Russian authorities in the Caucasus, then, as a rule, those problems have been touched upon as an attendant line in the corpus of the works of the generalized type connected with the research on the general socio-economic, socio-political or socio-cultural development of the territory in question in the XIXth century (Bliev, 2004, p. 877; Degoev, 2001, p. 443; Derlugian, 2013, p. 155; Zakharova, 2001, p. 338; Udovik, 2004, p. 258; Fadeev, 1960, p. 398).

At the same time charity that has become the object of the research, is not new in itself, but was innovative in the Caucasus in the time under study, and prince M. S. Vorontsov was a pioneer in its broad and systematic use. In this sense prince governor-general was introducing the Caucasus to the new European in its nature norm of the social life, which was exceptionally important for the territory exhausted for a prolonged period by all kinds of confrontation and opposition.

Charity in this case did not only encouraged help to concrete people, but accustomed the local dwellers (natives and immigrants), who had suffered hardship and deprivation, to the new form of social solidarity, developing in them the principles of civil involvement.

The medical aspect of the declared problem also has the specific feature that is interpreted as the activities of the governor-general targeted at the protection of the population of the entire Caucasian territory, both Russian and native Caucasian dwellers, as a compulsory and merciful function of the imperial state system that was becoming firmly established in the territory, which, nevertheless, is connected particularly with the personality of prince M. S. Vorontsov.

In connection with the fact that the Caucasus as a part of the Russian Empire and as the part of modern Russia is drawing rapt attention of the people concerned with this region-researchers of all directions, politicians, diplomats, administrators and military men-the subject of the research declared in this article can promote understanding of the essential mechanisms of the development of this region and, at the same time, requires further detailed study.

The authors of this article have selected and analyzed the documentary sources of the appropriate time, the memoirs literature of the contemporaries and the direct participants in the period under study, and also the works 
of the modern researchers of the Caucasian old times that have enabled us to propose our own interpretation of the two aspects of the unfolding events.

\section{Method}

The process of getting to the point of the declared problems relied to a great extent on the use of a number of methods, for example, the method of the synchronous and diachronous analysis, which enabled us to monitor the step-by-step discovery of the dynamics of the changes in the structure of the reforming activity of prince M.S. Vorontsov in the Caucasian region during a certain period of time; to reveal the properties and functions of each of his undertakings as the foundation on which subsequent work on the inclusion of the Caucasus in the world of the Russian socium has been built and accomplished.

The historical-genetic method enabled us to discover the sources which were the building blocks of the whole reforming strategy of prince M. S. Vorontsov and his team, due to which the authors of this article obtained the set of instruments to build their hypothesis approximated to the realias that had existed in the Caucasian region in the mid-XIXth century.

\section{Results}

The Caucasus region, as a newly acquired part of the Russian Empire, in the 40s-50s of the XIXth century had undergone the problems of its formation. The local Caucasus administration lacked competent and skilled people and peaceful life for the socio-political and cultural development and regulation of the economic life. Quite often there was a banal shortage of elementary material means. Besides the authorities often encountered lack of understanding on the part of the local Caucasian dwellers, who were only going to realize, accept and adapt to the new conditions of existence that were taking shape in the region.

The new forms of civil life could not take root all by themselves. The governor-general of the Caucasus, prince M. S. Vorontsov with his administration managed to give this process a new dimension, but the solution of the emerging tasks could not remain utterly and completely within the official limits.

It was essential to find ways of relying on the local public forces in order to find the proper course towards the economic and socio-cultural prosperity of the region.

There where the state encumbered with immeasurable responsibility would make a stop, the public-private initiative could continue functioning. The public forces were not only free from the encumbrance with formal obligations, but they existed right in the midst of the daily life not always understood in all its diversity by the formalized bureaucratic volition.

Prince M. S. Vorontsov, as it has been repeatedly noted, was not only a high-ranking efficient bureaucrat, but also a skillful diplomat and a successful businessman. Only a person like him with a set of qualities of this kind could in embarrassing situations afford to appeal to all and everyone, capable of and willing to participate in the building of the political system in the Caucasus region not only under compulsion, by virtue of their status, but of their own free will.

When his powers as the governor-general were not sufficient enough, he boldly appealed to the public initiative by sending the appropriate encouraging signals. The governor-general always called upon the people to treat public needs actively and effectively, promoted any charity initiatives.

The essence of philanthropy "is rendering by private persons or their associations of the material support and assistance to all those who need them, and also participation in socially significant events on the basis of the voluntary expression of their will. $<\ldots>$ Private charity was the reaction of the compassionate people regarding those who were suffering hardship, misfortune, and privation, doing good to one's neighbour was a moral obligation with the people who felt the need for this" (Lazaryan, 2003; Zarubina, 2001, p. 105).

Charity as good deed (V. I. Dal') was the reflection of the established moral principles, of the moral duty of the well-to-do people to render assistance to the poor. This activity was beginning to assume the characteristic of the public mission which people were proud of and where they found the realization, among others, of their different diverse ambitions and claims.

Besides, having been introduced to the cultural values in the British school of education, prince M. S. Vorontsov fixed in his mind a compulsory norm for the representatives of the aristocratic environment-philanthropy or benevolence. To be an aristocrat and not to be a philanthropist is nonsense, even a scandal. "England has always been famous for its wide range of philanthropy" (Soroka, 2010, p. 50; Trevelyan et al., 2001, p. 427). This became part of the society's existence. It was philanthropy that the prince governor-general aspired to inculcate first in Tiflis and then in the entire Caucasus region. 
In Russia by force of tradition the majority of the donors and philanthropists were merchants and entrepreneurs. And by force of the increased religiosity, widely spread in this social stratum, which dictated the rules of social behaviour, those people were longing to find the heavenly grace through the virtues of the earthly life based on the Ten Commandments of the Gospels (Khorkova, 1998).

The society offered for the donors and philanthropists various opportunities for the realization of their intentions. The governor-general invariably supported the donations to educational establishments. Moreover prince M.S. Vorontsov himself and his wife-the princess were the direct participants in those donations. The Vorontsov's couple total donations to the development of education in the Caucasus amounted to 300-400 thousand roubles (Zisserman, 1874, p. 95).

The cause of philanthropy in favor of the educational establishments in the Caucasus was greatly promoted by the journey to the Caucasus in 1850 of cesarevitch Alexander Nikolaevich. The heir to the throne gave orders that every year one female pupil be educated in the Trans-Caucasian Institute for girls at his expense.

Inspired by this example or by the wish to imitate the ruling persons or for some other reasons, the nobles of Stavropol guberniya also offered to keep at their expense in one of the military schools 5 cadets from the children of the poorest nobles of Stavropol guberniya. This initiative was met with understanding and approval not only on the part of the governor-general of the Caucasus, but also in St. Petersburg (Berzhe, 1885, p. 898).

In their turn the merchants of Stavropol guberniya did not shun this activity, did not want the nobles to surpass them. The representatives of the guild of merchants decreed that in the course of 25 years one thousand two hundred roubles be deposited every year so that one thousand roubles are spent on the tuition in Stavropol St. Alexandra women's educational establishment of 25 daughters of the poorest citizens as half-boarders. The selection of the girls was conducted under the supervision of the local Duma. The rest two hundred roubles were to be sent as a benefit to these girls both during the period of their study and subsequently (Berzhe, 1885, p. 898).

In 1854 princess E. K. Vorontsova donated 200000 roubles in silver to 5 women's charity institutions founded under her patronage. Besides the princess gave orders that every pupil on graduation be granted the benefits of 200 roubles (Zakharova, 2001, p. 338).

Donations to some other needs were made largely "for the sake of public benefit, but not for the sake of the lords' fun and uncontrolled whims" (Zisserman, 1874, p. 95). For example, M. S. Vorontsov spent large personal sums of money to invite skilled gardeners and wine-growers from abroad in order to put these branches of the economy in the vast region on a rational footing. He also ordered from France and Germany grapevine and seedlings of many fruit-trees and distributed them among those who wished for free (Ogarkov, 1892, p. 76).

When travelling over the region or making marches with his troops, the prince always gave the guards of honor, orderlies, riflemen 25-40 copecks per man for valor and conscientious service (Zisserman, 1874, p. 95).

M. S. Vorontsov was not indifferent to the fates of individual people either. For example, during his stay in Temir-Khan-Shurah in 1848, a widow of the staff-captain of the Apsheron regiment who had been left with two children without any means of subsistence petitioned the governor-general through prince A.M. Dondukov-Korsakov.

Prince M. S. Vorontsov granted her a generous benefit, and afterwards princess E. K. Vorontsova found a place for the captain's widow in Stavropol and took her children into her home (Dondukov-Korsakov, 2000, p. 430).

Princess Vorontsova, whenever an opportunity presented itself, always paid attention to the desperate situation of the daughters of the Caucasian officers. It was just for this very reason that thanks to her care and donations the aforesaid educational establishments in Tiflis, Stavropol and Erivan for the daughters of the servicemen in the Caucasus had been organized, which "secured the fortunes of hundreds of the orphans and children of the officers whom military service had taken to the Caucasus" (Dondukov-Korsakov, 2000, p. 430).

No less sympathy was extended by M. S. Vorontsov to the fate of the commander of the 20th infantry division general P. P. Nesterov, who had happened to lose his reason. In order to protect the sick man from the impressions, created by the local circumstances, that had had a disastrous effect on his mind, the governor-general ordered that P. P. Nesterov should be dispatched from fortress Groznaya to Pyatigorsk without delay, but this measure proved insufficient for the recovery.

On doctors' advice Prince M. S. Vorontsov in the hope of relieving the lot of his colleague, dispatched general P. P. Nesterov far away from the Caucasus to Moscow, "where with the large sums of money at his disposal one can expect a better outcome of his disease" (Berzhe, 1885, p. 898). The general in his journey was escorted by the 
military physician Sokolov and the general's aide-de-camp lieutenant Kurillo.

Besides, Prince M. S. Vorontsov gave some notification in this connection to the military governor-general of Moscow. The governor-general of the Caucasus asked the latter to put the sick P. P. Nesterov under his protection, to entrust him to the care of the experienced doctors, to accommodate him in apartments or to place him in Moscow military hospital, "without turning, unless as a last resort, to drastic measures, which could produce a harmful impression on the patient" (Berzhe, 1885, p. 898).

The governor-general also petitioned the war minister Prince A. I. Chernyshov "to obtain" the permission of His Imperial Majesty regarding general P. P. Nesterov's maintenance in Moscow which, up to his full recovery, "would secure him a successful medical treatment and financial support for his family" (Berzhe, 1885, p. 898).

The war minister in May 1851 informed the Prince Governor-general that the Emperor had approved of all his instructions concerning general P. P. Nesterov, and ordered that the general for the period of his disease be paid the money allowance he had received according to the military rank of the commander of the 20th division.

When baron P. P. Meller-Zakomelsky, commander of the Kurinsk regiment, reported to prince M. S. Vorontsov, that during the march to the mountains, the horse of V. A. Poltoratsky had been killed under him, the commander-in-chief asked in future to make it an indispensable rule "to honestly report to him on his regiment's officers' killed horses, so that he would send the commander 60 roubles per each horse" (Poltoratsky, 1893, p. $82)$.

The allocated sum was no small considering that a good Cabardian saddle at that time cost 24 roubles, and the horse-35 roubles (Poltoratsky, 1893, p. 82).

For many people connected with the Independent Caucasian Corps (ICC), such behavior of the governor-general and the commander-in-chief was not unusual as the spirit of comradeship and solidarity had always been there. In the same Temir-Khan-Shurah, Anna Efimovna Klyugenau, according to A. M. Dondukov-Korsakov, "was the providence of the poor officers in Shurah, was nursing the wounded with touching consideration and together with her husband had never refused, with their meagre means, help to the families and orphans of the fallen officers" (Dondukov-Korsakov, 2000, p. 430).

The governor-general saw to it that in Tiflis they organized help to the people in need who had been reduced to poverty. For those, who "due to the injury or decrepitude were no longer able to earn their own living by work" (Udovik, 2004, p. 258), from 1850 the local hospital and the Pokrovsk barracks had opened canteens for 60 men each. The people in need were given though not sumptuous, but sufficient and healthy food.

The money for the maintenance of the canteens for the poor, roughly 2413 roubles and 87.5 copecks, was granted from the extraordinary sums that were under the authority of the official of the Trans-Caucasian Department of public care entrusted with the management of the canteens (Berzhe, 1885, p. 898).

To help the people in need Prince M. S. Vorontsov could resort to extraordinary measures. Thus, in 1851, on the initiative of the governor-general, the Trans-Caucasian Department of public care set up a savings bank to deposit and save small sums of money. The deposit from one person was no less than 50 copecks and no more than 25 roubles at a time with the accrual of 4 per cent per 100 per cent of the deposit, but on condition that the total deposit per one man did not exceed 750 roubles (Berzhe, 1885, p. 898).

The setting up of the savings bank of this kind was aimed at "providing the poor people of all ranks with the means of saving in a reliable and profitable way the small remainder from the expenses, to keep it for future use" (Berzhe, 1885, p. 898).

This way of helping the poor people was for the Caucasus in general and for Tiflis in particular a new measure, and therefore for some time it remained hard to understand for the local dwellers. But gradually as the essence of this way and its benefits were understood it proved a great success.

Naturally the search for the solution of the public needs was not limited to charity alone. Prince M.S. Vorontsov had in his arsenal enough means given to him by his official status as the imperial governor-general in the Caucasus.

Having noticed the shortcomings in the work of the town hospital in Tiflis, the Prince Governor-general commissioned the inspector of the medical board and one of the officials attached to him to inspect the hospital and look deep into all the details of the matter. The inspection was followed by the corrective measures aimed to improve the hospital building itself and the conditions of the maintenance of patients (Berzhe, 1885, p. 898).

In the town hospital in Tiflis in the course of 1846 , for example, 452 patients were receiving treatment; the daily maintenance of each of them came to 45.5 copecks in silver (Berzhe, 1885, p. 898). 
The repairs of the town hospital building itself took a long time: from November, 14, 1847 to December, 11, 1848. In this connection the patients of the civil department, by order of the Prince Governor-general, were sent for treatment to the military hospital that was 5 versts (verst $=3500$ English feet) away from the town. On the completion of the repair work the town hospital could receive up to 50 people who needed hospitalization.

The governor-general was also preoccupied with the fact, that the hospital in Tiflis was disadvantageously located far from the center of the town, on the other side of the Kura river. He began pondering whether the opportunity to build a new hospital in the center of the town without any additional costs involved would present itself, and whether other establishments, like an almshouse, a lunatic asylum and others could be moved to the old building of the town hospital.

At the end of 1845 the epidemic of smallpox spread all over Tiflis. Various factors contributed to this: ineradicable prejudice of the population against vaccination, poor quality of the vaccine itself, lack of the proper habit and the proper level of the hygienic culture, especially among the poor strata of the population.

The governor-general without delay ordered the medical department to take the most effective measures to stop the dangerous disease. With that end in view the town was divided into several sectors, and each sector was under the supervision of a special medical man. The governor-general gave instructions to order new smallpox matter and vaccinate cows against the smallpox. After several experiments a good-quality vaccine for the inoculation of the population was obtained (Berzhe, 1885, p. 898).

Despite the fact that in the time of Prince M. S. Vorontsov Tiflis was gradually turning into a "European town", which was noted by the contemporaries (Pirogov, 1952, p. 56), the town, however, as the entire Caucasus region, experienced on the whole an acute shortage of doctors.

The situation was changing slowly, even after the increased arrivals of the doctors from Russia. The increased need for medical services stimulated by the influx to the Caucasus of the contingents of new settlers necessitated the search for the acceptable solutions.

The governor-general initiated the sending off of the local Caucasian natives to Moscow to learn medicine. Of all the local residents of Georgia it was chiefly Armenians who responded to his appeal. They willingly sent their children to Russian universities to learn medicine. The result was that by the end of the 40 -s there had been a sufficient number of doctors of the Armenian origin in the Russian service.

At the same time owing to the habits of the local population and the surviving mistrust of the Russians, especially on behalf of the Muslims, "the local healers" did not go out of fashion either (Pirogov, 1952, p. 56). The local healers practiced extensively in everyday life. The local population for fear of the Russian doctors, kept turning to the local healers for medical aid, so that in case of illness they were not left without "any medical relief" (Berzhe, 1885, p. 898).

The Russian authorities were trying to streamline their practice and put it under the control of Tiflis medical department.

Legal medical practice was allowed only to those local native quack doctors who had taken an examination in Tiflis medical department and got the certificate giving them the right to treat sick persons (Berzhe, 1885, p. 898). But very few risked taking the examination. Therefore in Tiflis, not to mention other places, a considerable number of popular doctors carried on with their practice.

For example, in childbirth, instead of certified doctors, midwives were sent for, even to rich homes. The prestige of midwives among the inhabitants was so high that even in case of difficult deliveries they practically never called in doctors. Soon after the birth, the baby in Georgian families was washed with water diluted with wine. With the Armenians-the head and body of the new-born child was sprinkled by the midwife with salt, which was considered an amulet (Anchabadze \& Volkova, 1990, p. 195).

Due to the fact that quackery was often practised by the people with insufficient knowledge or experience, not infrequent were the cases that led to dangerous consequences for the health of the people. The incident that occurred to the resident of Tiflis, M. Abramov, who having turned for medical aid to local quack S. Papumov, "got from his medicines the confusion of his entire organism", can serve as an example (Berzhe, 1885, p. 898).

The incidents of this kind occurred repeatedly, which compelled the Russian authorities to place a ban on the medical practice of the local quacks already in 1845 "for the protection of the society against the harm that can be done through the inexperience of the persons engaged in rendering medical aid to sick people" (Berzhe, 1885, p. 898).

But due to the shortage of doctors the attempt to resolve the problem once and for ever was a failure. Besides the 
local quacks thanks to the great demand for their services and lucrativeness of the medical profession resorted to tricks and cheating to legalize their practice.

The same resident of Avlabar S. Papumov, having obtained from the inspector of Tiflis medical department Depner the certificate to the effect that he has "enough knowledge in the art of bone-setting and treatment of the external wounds", provided services that exceeded the bounds of his medical knowledge to the people, who were badly in need of treatment (Berzhe, 1885, p. 898).

After M. Abramov's complaint, Tiflis medical department deprived S. Papumov of the certificate given out by Depner and placed a ban on his medical practice.

At the same time the situation connected with the proper medical service of Tiflis population did not remain the same. Gradually, as the doctors from Russia kept coming or on receiving such diplomas by the local residents who had been trained in the Russian educational establishments, the situation was changing for the better. At least the aristocratic and educated circles, in case of need, began to turn to certificated specialists for help.

This was promoted to a greater extent by the governor-general's civilizing measures, which began to change the structures of the daily occurrence and the very mentality of the Georgian and then the entire Caucasian nobility (Derlugian, 2013, p. 155).

At the doctors' and their patients' disposal in Tiflis there was a public chemist's shop where medicines were only available on prescription and one private chemist's shop.

They also prepared pack chemist's shops for the uezd and town doctors and the required medicines were regularly supplied to them (Derlugian, 2013, p. 155).

During the military expeditions to the mountains prince M. S. Vorontsov had always demonstrated a heightened interest in the wounded soldiers and officers. This was not only part of his duty as a commander, but also the characteristic of the human nature.

This attitude to his subordinates in all its fullness was already displayed in Dargin expedition in the summer of 1845. When at the very start of the expedition the first wounded from the detachment of general D. V. Pasek were dispatched to the main forces, they were received with great care and the keenest sympathy. M. S. Vorontsov "gave them money, a subscription list was opened in their favour, and to take them to Temir-Khan-Shurah the prince gave the order to choose the best chervodar horses" (Lisitsyna, 2001, p. 260).

M. S. Vorontsov personally thanked those who had distinguished themselves in action, embraced them and shook hands with them despite the blood and mud that covered the wounded. When one of the soldiers warned the prince that he was soaking wet, covered in blood and mud, the commander responded that "this mud does not stain" (Beklemishev, 2001, p. 541).

He gave one of the non-commissioned officers a gold watch and ten half-imperials (imperial-Russian gold coin of 10 or, after 1897,15 roubles) and the Cossack whose greatcoat had been shot through in eleven places received from M. S. Vorontsov 11 gold coins (Beklemishev, 2001, p. 541).

When the main detachment was breaking out of encirclement, it had and excessive number of wounded people (1200 people), who were being carried on stretches. The field hospitals had not enough bandaging material. A greater part of the people was weakened to utter exhaustion, apart from wounds, by the rampant dysentery. M.S. Vorontsov regularly inspected the marching column, talked with the wounded, encouraged those who had lost heart (Beklemishev, 2001, p. 541).

When the remainder of the detachment after many days of trials and starvation arrived in Gerzel-aul, by order of the command about 10000 churecks (kind of unleavened flat bread made in the Crimea and the Caucasus) were made for the distribution both among the officers and the soldiers. On the same day the governor-general together with general P. K. Freitag on horseback reviewed all the units of the troops, greeted the people and thanked them (Shwartsenberg, 2001, p. 518).

Prince M. S. Vorontsov, as the commander of the ICC, was duty-bound to take immediate measures to create conditions to preserve and keep up at the proper level the health of the staff of the corps entrusted with him. The task was extremely important and extremely complicated because the health of the troops was indissolubly linked to the health of the whole nation.

During the reign of Nicholas I the health of almost the entire population was unsatisfactory (Kulvin, 1908), and numerous wars of the previous rule and famine in almost all areas had undermined the national well-being (Varadinov, 1863, p. 494). 
During the military service a soldier suffered all kinds of hardship from the first days of his regimental life. The additional trials for the recruits, sent to serve in the Caucasus, were the specific features of the local climate, exhaustion from expeditions and campaigns in the conditions of the mountainous-woodland landscape and the extraordinary broken ground, malnutrition. All this, in the aggregate, was the main cause of the considerable morbidity and mortality in the troops, not to mention fatal casualties. This was especially related to the young recruits recently sent to the Caucasus from the country's interior.

What was needed to preserve their health and counteract the morbific causes was, as a minimum, good food in a sufficient amount, good accommodation for everyday life and the clothes comfortable to the seasons of the year and conditions of the residence.

\section{Discussion}

The scientific significance and the practical need for the research into the problems raised in the article are determined by the fact that the article analyses the historical experience of the development of the Caucasian region that used to be the problem territory of the Russian Empire. Many of the approaches and methods of the solution of the tasks of the past are not only by any means outdated, but they put a new spin due to their actualization towards the turn of the XXI century.

\section{Conclusion}

The social orientation of the activities of the governor-general of the Caucasus prince M. S. Vorontsov was concrete and purposeful in character. The prince would not simply fulfill the task entrusted with him by the emperor of the speediest possible pacification of the Caucasus and its integration with the Russian Empire, as its constituent part, but would aspire to set the scene for the form of the social daily routine, new to the Caucasus, would develop social solidarity through the broadest involvement of all the public forces capable of charity, would strengthen the institutions targeted at the protection of the health and life of all the strata of the population of the Caucasian region.

The authors of this article believe that the presented material will enable all the people concerned who are in any way related to the Caucasus or the Russian-Caucasian relations to see the processes of the past in a new light and appreciate the activities of prince M. S. Vorontsov by avoiding the established ideological and political prejudice. In the end this will promote understanding of the fact that Russia has succeeded in winning support of the greater part of the Caucasian socium.

At the same time it should be noted that the authors of this article are planning to broaden both the corpus of the historical facts and their interpretation in order to get the answers to how the Russian authorities have succeeded in shifting the initial irreconcilability of the part of the Caucasus with them to the direction of the constructive coexistence within the framework of the Russian state system.

\section{References}

Anchabadze, J., \& Volkova, N. (1990). Old Tbilisi. The town and the townspeople in 19th century (p. 195). Moscow: Nauka.

Beklemishev, N. (2001). The military campaign of count Vorontsov in Dargho and "Sukarnaya expedition" in 1845. In The tragedy of Darghin (p. 541). Saint Petersburg: Izdatelstvo of the "Zvezda" magazine.

Berzhe, A. (Ed.). (1885). Acts collected by the Caucasian commission for the study and publication of early texts (CCSPET) (Vol. 10, p. 898). Tiflis.

Bliev, M. (2004). Russia and the mountain-dwellers of the Greater Caucasus. On the road to civilization (p. 877). Moscow: Mysl.

Degoev, V. (2001). The Big Game in the Caucasus: History and the present time (p. 443). Moscow: Russian panorama.

Derlugian, G. (2013). How this world is organized. Sketches on macrosociological themes (p. 155). Moscow: Izdatelstvo Instituta Gaidara.

Dondukov-Korsakov, A. (2000). My reminiscences. In The siege of the Caucasus (p. 430). Saint Petersburg: Izdatelstvo of the "Zvezda" magazine.

Fadeev, A. (1960). Russia and the Caucasus in the first third of the XIXth century (p. 398). Moscow: USSR Academy of Sciences Publishing House.

Khorkova, E. (1998). The history of entrepreneurship and patronage in Russia. Moscow: Izdatelstvo PRIOR. 
Kulvin, N. (1908). Historical study of the development and activities of the military medical department in the reign of emperor Nicholas I. In Centenary of the War Ministry. Study of the development of the military medical department (Vol. 8, part 2, p. 151). Saint Petersburg.

Lazaryan, S. (2003). The growth of entrepreneurship in the KMW region. Pyatigorsk: Spetspechat.

Lisitsyna, G. (2001). Reminiscences of count K. K. Benkendorf. In The tragedy of Darghin (p. 260). Saint Petersburg: Izdatelstvo of the "Zvezda" magazine.

Ogarkov, V. (1892). The Vorontsovs. Their life and public activity (p. 76). Saint Petersburg.

Pirogov, N. (1952). The account of the journey across the Caucasus (p. 56). Moscow: Izdatelstvo meditsinskoy literatury.

Poltoratsky, V. (1893). Reminiscences. Historical Bulletin, 1, 82.

Shwartsenberg, E. (2001). The military actions in the Caucasus in 1844 and 1845. In The tragedy of Darghin (p. 518). Saint Petersburg: Izdatelstvo of the "Zvezda" magazine.

Soroka, M. (2010). "Enlightened navigators": the English in the perception of the Russians before and during the First World War. Russian History, 5, 50.

Trevelyan, G., Krushinskaya, A., \& Tatarinova, K. (2001). English history, Chaucer to Queen Victoria (p. 427). Smolensk: Rusich.

Udovik, V. (2004). Vorontsov (p. 258). Moscow: Molodaya Gvardia.

Varadinov, N. (1863). History of the Interior Ministry (Vol. 8, part 2, book 2, p. 494). Saint Petersburg.

Zakharova, O. (2001). General-fieldmarshal His Highness prince M. S. Vorontsov. The Knight of the Russian Empire (p. 338). Moscow: Tsentrpoligrapg.

Zarubina, N. (2001). The Orthodox Christian entrepreneur as reflected in the Russian culture. Social Sciences and Modern Times, 5, 105.

Zisserman, A. (1874). On the polemics regarding prince M. S. Vorontsov and N. N. Muraviov as governors-general of the Caucasus. Russian Bulletin, 114(11), 95.

\section{Copyrights}

Copyright for this article is retained by the author(s), with first publication rights granted to the journal.

This is an open-access article distributed under the terms and conditions of the Creative Commons Attribution license (http://creativecommons.org/licenses/by/3.0/). 